\title{
Mycorrhizae: Implications for Environmental Remediation and Resource Conservation $^{1}$
}

J. Sharma, A.V. Ogram, and A. Al-Agely ${ }^{2}$

Fungi are common in aquatic and terrestrial environments, absorb the nutrients they need, and occur as either free-living or in symbiotic forms. In terrestrial environments, fungi are of fundamental importance as decomposers, plant pathogens, symbionts, and in biogeochemical cycles. In soils, fungi can comprise the largest pool of biomass. To date, there are an estimated 1.5 million species of fungi on the planet, of which fewer than 80,000 have been identified.

Mycorrhizae (singular "mycorrhiza") are symbiotic relationships between plant roots and one or more fungi. The Greek words mycos, meaning "fungus," and rhiza, meaning "root," were combined to classify this relationship between organisms belonging to two different kingdoms. The mycorrhizal condition is a "norm" for most plants because up to $80 \%$ of the flowering plants (angiosperms) and up to 95\% of all plants form mycorrhizal relationships. Photosynthetic plants support the fungi by providing fixed carbon (up to $20 \%$ of the photosynthate may be allocated to roots to support mycorrhizae) and nutrients; the fungi in return provide the main plant-growthlimiting nutrients, nitrogen and phosphorus. Mycorrhizal non-photosynthetic plants rely on the fungal partners for carbon in addition to the nutrients. It is thought that the non-photosynthetic plants may be parasitizing the fungi because degradation of fungal hyphae inside the root cells is documented.

Mycorrhizae are broadly classified into two functional categories: (1) ectomycorrhizae; and (2) endomycorrhizae. Ectomycorrhizal relationships involve colonization of space between the cortical cells of roots and formation of a fungal sheath on the outside of the root. Endomycorrhizal relationships involve colonization of space within the cortical root cells. In addition, the mycelium (a network of fungal hyphae) extends into the soil in both cases, thereby vastly extending the area available for the absorption of water and nutrient elements. The fungal partner(s) in mycorrhizae may account between $80 \%$ and $100 \%$ of phosphorus (P) taken up by a plant. There is now increasing evidence for nitrate and ammonium uptake by plants via mycorrhizal relationships.

1. This document is ENH1086, one of a series of the Environmental Horticulture Department, Florida Cooperative Extension Service, Institute of Food and Agricultural Sciences, University of Florida. Original publication date November 2007. Visit the EDIS Web Site at http://edis.ifas.ufl.edu.

2. $\quad$ Dr. Jyotsna Sharma, Assistant Professor, Environmental Horticulture, University of Florida, Quincy, Florida, 32351. E-mail: jyotsna@ufl.edu. Dr. Andrew V. Ogram, Professor, Soil and Water Science, University of Florida, Gainesville, Florida 32611. Dr. Abid AlAgely, Senior Biologist, Soil and Water Science, University of Florida, Gainesville, Florida 32611.

The use of trade names in this publication is solely for the purpose of providing specific information. UF/IFAS does not guarantee or warranty the products named, and references to them in this publication does not signify our approval to the exclusion of other products of suitable composition.

The Institute of Food and Agricultural Sciences (IFAS) is an Equal Opportunity Institution authorized to provide research, educational information and other services only to individuals and institutions that function with non-discrimination with respect to race, creed, color, religion, age, disability, sex, sexual orientation, marital status, national origin, political opinions or affiliations. For more information on obtaining other extension publications, contact your county Cooperative Extension service. U.S. Department of Agriculture, Cooperative Extension Service, University of Florida, IFAS, Florida A. \& M. University Cooperative Extension Program, and Boards of County Commissioners Cooperating. Larry Arrington, Dean. 
Beyond the two functional categories (ecto- and endomycorrhizae), mycorrhizae are further classified into different groups based on the interacting organisms and mycorrhizal morphology. For example, ericaceous plants (e.g., Calluna, Erica, Vaccinium, and Rhododendron) form what are termed "ericoid mycorrhizae." Similarly, several other groups such as arbutoid mycorrhizae, monotropoid mycorrhizae, orchid mycorrhizae, etc., are classified based on specific associations between certain types of plants and fungi. These associations involve ecto-, endo-, or a combination thereof in forming the various mycorrhizae.

Ectomycorrhizae are commonly found in the boreal and temperate deciduous forest trees in the genera Pinus, Picea, Larix, Betula, Salix, Fagus, and Quercus. These mycorrhizae exhibit a short, branched structure, and mycelia can often be seen on the outside of the root (Figure 1).

Figure 1. Short, branched ectomycorrhizae of Pinus taeda (loblolly pine) growing in north Florida. The segment shown is $1.5 \mathrm{~cm}$ in length. Photograph: Jyotsna Sharma.

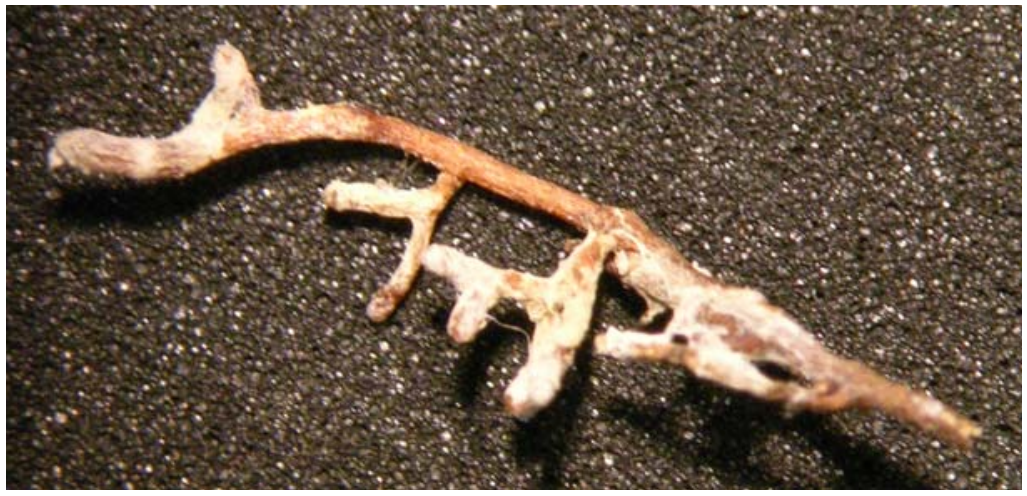

Arbuscular mycorrhizae, or AM, are the most common type of endomycorrhizae, and known to have originated 460 Million Years Ago (MYA). These fungi are obligate symbionts occurring with most herbaceous and woody plants throughout the temperate deciduous forests, grasslands, and sub-tropical and tropical regions in savannas and rainforests (Leake, 2007). The arbuscule, a highly branched hyphal structure that forms within the cortical root cells, is of central importance in AM because nutrient exchange occurs across the interface between the arbuscule and the cellular contents (Figure 2).

Figure 2. The arrows on the left panel point to arbuscules, which are characteristic of arbuscular mycorrhizae (endomycorrhizae) and provide the interface for nutrient transfer between the fungus and the plant cell. The arrows on the right panel show vesicles, used for storage of carbon by the fungus within the plant cell. Images: Abid Al-Agely.
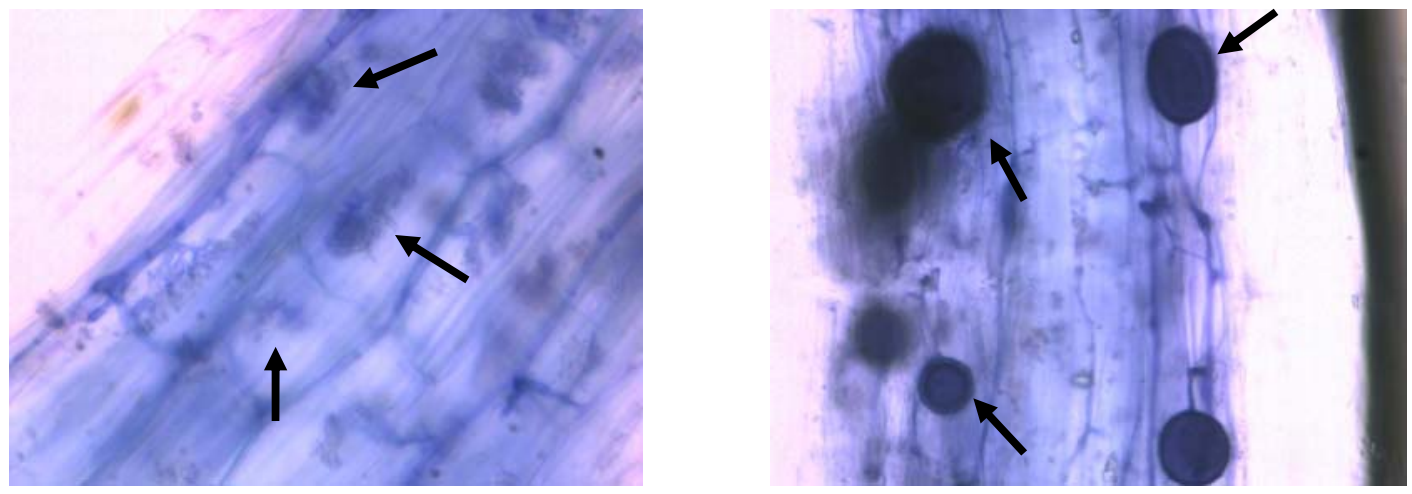


\section{Importance of Mycorrhizae for Environmental Remediation and Resource Conservation}

Mycorrhizae and Environmental Remediation

Environmental remediation is defined as the removal of pollution or contaminants from environmental media such as soil, groundwater, sediment, or surface water for the general protection of human health and the environment. In the plant rhizosphere (the zone of soil under the direct influence of a plant root), biodegradation or transformation of pollutants by rootassociated bacteria and fungi under the influence of select plant species occurs. Plants can increase the total numbers of beneficial fungi and bacteria in contaminated soil from a general rhizosphere effect. This is substantiated by the observation of higher microbial biomass and activity in the rhizosphere (Olson et al., 2003). From the successive use of select vegetation and sound plant management practices, rhizosphere activity can lead to transformation and removal of compounds of interest.

Mycorrhizae have been suggested to improve biodegradation of recalcitrant (persistent) organic pollutants because of the immense size and very high surface interface with soil. These fungi have enzymes which are known to metabolize and degrade compounds such as polychlorinated biphenyls (PCBs) and polycyclic aromatic hydrocarbons (PAHs) (Olsen et al., 2003).

Inoculation of plant roots with arbuscular mycorrhizal fungi has also been reported to enhance the phytoaccumulation of heavy metals zinc (Zn), cadmium (Cd), arsenic (As), and selenium (Se) (Khan et al., 2000; Al-Agely et al., 2005). It has been shown that water-insoluble carbonate forms of $\mathrm{Zn}$ and $\mathrm{Cd}$ can be changed to water-soluble forms by the activities of endomycorrhizal hyphae (Giasson et al., 2005). Spores of arbuscular mycorrhizal fungi in the genera Glomus and Gigaspora have been isolated from most of the plants growing in heavy-metal-polluted sites. It is also known that fungi from metal-contaminated sites are typically more tolerant to heavy metals compared to the reference strains from uncontaminated soils. Most of the amelioration of contaminated soils is believed to result from the protective effect of the fungal hyphae, which create a physical or chemical barrier against the uptake by plants of heavy metals. These compounds bind to the fungal cell wall components such as chitin, cellulose derivatives, and melanin. However, heavy metal removal by mycorrhizal plants is variable, ranging from highly effective to limited efficacy. In general, the combination of the fungus and plant species determines the efficacy of the uptake and removal of elements. The concentration of the contaminant element in the substrate also influences the efficiency of removal by the mycorrhizal plants.

Mycorrhizae also improve the remediation potential of plants by producing plant-growthstimulating substances and by encouraging mineral nutrition, better general growth, and high biomass necessary for plant-based remediation. Plant growth also benefits because these fungi, along with other microorganisms, improve soil structure.

Currently, a limitation for the application of specific mycorrhizal associations for remediation is that the beneficial effects depend on the combined efficacy of plants and the fungi involved, and also on their ecological interactions within the system (soil, water, sediment, etc.) in which the contaminant is present. While there can be a general beneficial effect of microbial communities, individual plant-fungus combinations can vary in their efficacy in removal of pollutants from the 
environment. Selection of the most effective combination of plants and fungi is very important for achieving the desired benefits.

\section{Mycorrhizae and Resource Conservation in Commercial Plant Production}

In agricultural and horticultural crop production, application of large amounts of fertilizers and pesticides is accepted, and is normal practice (Smith and Read, 1997). While there are many examples of improved crop productivity in mycorrhizal plants, there are few examples of largescale inoculation or management carried out in mainstream commercial production. The possible benefits of mycorrhizae in plant production are: (1) increased crop yield; (2) reduced fertilizer and pesticide inputs; and (3) maintenance of a healthier soil system and resulting benefits such as improved water relations and reduced severity of some plant diseases.

Commercial sources of mycorrhizal inoculum are available, however the efficacy of particular fungal strains or of fungal mixes in improving nutrient uptake and plant growth is known only for few crops. In horticultural, containerized production of ornamental plants, mycorrhizal colonization has been shown to increase the number of buds and flowers, as well as shoot $\mathrm{P}$ and potassium (K) concentrations in Pelargonium peltatum (geranium). In other ornamental crops such as Ipomoea carnea ssp. fistulosa (bush morning glory), AM plants receiving 50\% of recommended rate of controlled-release fertilizer exhibited comparable or better growth, higher $\mathrm{N}, \mathrm{P}$, and $\mathrm{K}$ and marketability than non-AM plants at 100\% fertilizer rate (Carpio et al., 2005). Several other plants, such as Acacia greggii (cat claws), Plumbago auriculata 'Hullabaloo' (blue plumbago), Platanus occidentalis (sycamore), and Diospyros virginiana (common persimmon) showed similar increases in growth responses when inoculated with mycorrhizal fungi (Carpio et al., 2003).

Because mycorrhizal plants have greater access to nutrients and water in the substrate, the benefits of this symbiotic association in resource conservation in agriculture are important to consider. The network of fungal hyphae vastly extends the area available for absorption of substances required for plant growth, and thereby can help in reducing the inputs of fertilizers and water in agricultural and horticultural systems. For example, arbuscular mycorrhizae are very effective in helping plants absorb phosphorus from the soil, and phosphorus runoff is known to lead to eutrophication (= undesired biological growth and productivity in aquatic systems). Because agriculture is a source of phosphate pollution in the environment, increased phosphorus uptake by mycorrhizal plants can help reduce the quantity of this nutrient to be added to the soil, and decrease the accumulated $\mathrm{P}$ in soil and water.

The reduction in the occurrence of disease in mycorrhizal plants is a factor which needs consideration in integrated systems for pest management in agricultural systems. Mycorrhizae protect plants by competing with disease organisms for colonization sites, and by improving the nutrient status of the plant and thereby increasing the resistance of the plants to attack by pathogens. Mycorrhizal plants also may have increased tolerance of disease symptoms (Smith and Read, 1997).

In summary, mycorrhizae improve plant growth, help in contaminant removal, reduce the need for fertilizer application in commercial plant production, and improve the soil structure and 
health. Although relatively few specific plant-fungus combinations have been studied for their efficacy and application in remediation and resource conservation, the existing data on the benefits for mycorrhizae are promising.

\section{Literature Cited}

Al-Agely, A., D.M. Sylvia, and L.Q. Ma. 2005. Mycorrhizae increase arsenic uptake by the hyperaccumulator Chinese brake fern (Pteris vittata L.). Journal of Environmental Quality 34: 21812186.

Carpio, L.A., F.T. Davies, Jr., and M.A. Arnold. 2003. Effect of commercial arbuscular mycorrhizal fungi on growth, survivability, and subsequent landscape performance of selected container grown nursery crops. Journal of Environmental Horticulture 21: 190-195.

Carpio, L. A., F.T. Davies, Jr., M.A. Arnold. 2005. Arbuscular mycorrhizal fungi, organic and inorganic controlled-release fertilizers: Effect on growth and leachate of container-grown Bush Morning Glory [Ipomoea carnea subsp. fistulosa] under high production temperatures. Journal of American Society for Horticultural Sciences 130(1): 131-139.

Giasson, P., A. Jaouich, S. Gagne, and P. Moutoglis. 2005. Arbuscular mycorrizal fungi involvement in zinc and cadmium speciation change and phytoaccumulation. Remediation 15: 75-81.

Khan, A.G., C. Kuek, T.M. Chaudhry, C.S. Khoo, and W.J. Hayes. 2000. Role of plants, mycorrhizae and phytochelators in heavy metal contaminated land remediation. Chemosphere 41: 197-207.

Leake, J.R. 2007. Mycorrhizas and the terrestrial carbon cycle: roles in global carbon sequestration and plant community composition. Chapter 8 In Fungi in the Environment. Gadd, G.M., S.C. Watkinson, and P.S. Dyer (eds.). pp. 161-184. Cambridge University Press, Cambridge, UK.

Muchovej, R.M. 2004. Importance of mycorrhizae for agricultural crops. Document SS-AGR-170, Agronomy Department, Florida Cooperative Extension Service, Institute of Food and Agricultural Sciences, University of Florida, Gainesville. http://edis.ifas.ufl.edu/AG116.

Olson, P.E., K.F. Reardon, and E.A.H. Pilon-Smits. 2003. Ecology of rhizosphere bioremediation. Chapter 10 In Phytoremediation: Transformation and control of Contaminants. S.C. McCutcheon and J.L. Schnoor (eds.). pp. 317-353. Wiley-Interscience, John Wiley and Sons, Inc. Hoboken, New Jersey.

Perner, H., D. Schwarz, C. Bruns, P. Mader, and E. George. 2006. Effect of arbuscular mycorrhizal colonization and two levels of compost supply on nutrient uptake and flowering of pelargonium plants. Mycorrhiza 17(5): 469-474.

Smith, S.E. and D.J. Read. 1997. Vesicular-arbuscular mycorrhizas in agriculture and horticulture. Chapter 16 In Mycorrhizal Symbiosis. Second edition. Smith, S.E. and D.J. Read (eds.). pp. 453-69. Academic Press, London, UK. 